\title{
Sulfidity controls molybdenum isotope fractionation into euxinic sediments: Evidence from the modern Black Sea
}

\author{
Nadja Neubert ${ }^{1}$, Thomas F. Nägler ${ }^{1}$, Michael E. Böttcher ${ }^{2}$ \\ 'Institute of Geological Sciences, Isotope Geology Group, University of Bern, CH-3012 Bern, Switzerland \\ 2Leibniz Institute for Baltic Sea Research, Marine Geochemistry Group, Warnemünde, Germany, and Max Planck Institute for \\ Marine Microbiology, Biogeochemistry Department, Bremen, Germany
}

\begin{abstract}
Molybdenum (Mo) isotope fractionation has recently been introduced as a new proxy in oceanography and biogeochemistry. It is therefore fundamental to understand the processes controlling Mo partitioning into modern marine environments. This study identifies the availability of dissolved sulfide as the dominant control on overall Mo removal from the water column in euxinic systems. Mo isotopic composition of surface sediments from different localities of the Black Sea demonstrates complete fixation of Mo only below $400 \mathrm{~m}$ water depth, above a critical concentration of $11 \mu \mathrm{mol} \mathrm{l}^{-1}$ aqueous hydrogen sulfide in the bottom water. The Mo isotopic composition of these sediments reflects the homogeneous seawater isotopic composition of $2.3 \%$. In contrast, significant Mo isotope fractionation into less euxinic sediments is evident at shallower depths in the Black Sea, as well as in temporarily euxinic deeps of the Baltic Sea, consistent with the observed lower maximum sulfide concentrations in the respective water columns. Therefore, Mo isotope signatures in the modern Black Sea constrain the processes responsible for global Mo removal from the ocean by euxinic sediments. Furthermore, models of past ocean anoxia reconstruction have to consider that the seawater Mo isotopic composition is not per se archived in euxinic sediments.
\end{abstract}

Keywords: molybdenum isotopes, Black Sea, heavy stable isotopes, isotope fractionation, sulfidity.

\section{INTRODUCTION}

The Black Sea is the largest permanently euxinic recent water body on Earth and is the type system for euxinia in the geological past (e.g., Ross and Degens, 1974). Exchange of water between the modern Black Sea and the global ocean system is restricted by the Bosporus sill between the Mediterranean and the Black Sea. The development of anoxic conditions below the chemocline, at $\sim 100 \mathrm{~m}$ water depth, results from limited ventilation due to water column stratification. This is a consequence of higher salinity waters entering the Black Sea from the Mediterranean and less dense surface waters flowing out of the Black Sea (Konovalov et al., 1999). The surface water is oxygenated, with a salinity of $\sim 18 \mathrm{psu}$ (practical salinity unit; $1 \mathrm{psu}=1 \mathrm{~g}$ salt in $1 \mathrm{~kg}$ of seawater), which is influenced by the river water inflow (Murray et al., 1991). The water column below $\sim 150 \mathrm{~m}$ is permanently devoid of oxygen, with a salinity of $\sim 22$ psu (Murray et al., 1991). The sulfide concentration increases with water depth, reaching $400 \mu \mathrm{mol} \mathrm{L}^{-1}$ near the seafloor (Konovalov et al., 1999; Neretin et al., 2001). Sediments that accumulate under sulfidic bottom waters have been shown to have enhanced Mo contents (Crusius et al., 1996; Nägler et al., 2005).

Molybdenum isotope fractionation is a promising proxy for paleo-redox conditions of the Earth's oceanic system and atmosphere. Oxic seawater contains Mo as the stable oxyanion molybdate $\left(\mathrm{MoO}_{4}^{2-}\right)$ with concentrations of $\sim 0.11 \mu \mathrm{mol} \mathrm{L}{ }^{-1}$ (Emerson and Huested, 1991) and a homogeneous isotopic composition of $\delta^{98 / 95} \mathrm{Mo}+2.3 \%$ (mean ocean molybdenum, MOMo; Siebert et al., 2003). Its low chemical reactivity results in a relatively long residence time of $~ 800 \mathrm{ka}$ (Colodner et al., 1995; Emerson and Huested, 1991). Under sulfidic conditions, however, Mo is thought to be efficiently removed from the water column (Erickson and Helz, 2000; Helz et al., 1996).

The use of black shales as archives of Mo isotope signatures of coeval ocean water is a first-order approach based on the assumption of an almost complete molybdate scavenging that eliminates potential fractionation effects between the different pools. The mass balance between oxic and euxinic Mo sedimentation is then reflected in the Mo isotopic composition of ocean water, as these sedimentary environments show distinct Mo isotopic compositions. Thus, the relative proportion of oxic and euxinic environments governs the isotopic composition of the Mo remaining in solution (Barling et al., 2001; Siebert et al., 2003). This balance is complicated by the varying importance of suboxic sinks during geological time (Siebert et al., 2006). Black shales, formed under euxinic conditions, have been used to quantify paleo-redox conditions in the Neoproterozoic (Arnold et al., 2004) and the Early Cambrian (Lehmann et al., 2007), and to trace the initial rise of oxygen in the Archean (Siebert et al., 2003; Wille et al., 2007). These publica- tions demonstrated the general potential of Mo isotopes to approach first-order problems from the history of oxygen during important global environmental changes in the evolution of the Earth and the consequent evolution of life.

On the other hand, the redox-dependent Mo isotope signatures naturally lend themselves to the study of the evolution of recent euxinic seas and lakes. Those studies need a much higher resolution of both time and redox conditions and thus a more detailed understanding of the complex processes in the natural molybdenum cycle. In particular, various recent studies from different marine settings worldwide indicate the need for a better understanding of Mo scavenging mechanisms under reducing conditions (McManus et al., 2002; Poulson et al., 2006; Siebert et al., 2003, 2006). The transformation from chemically unreactive molybdate to highly reactive thiomolybdate under enhanced levels of dissolved sulfide has been proposed to be the prime reason for authigenic Mo enrichment in euxinic sediments (Erickson and Helz, 2000; Helz et al., 1996). The extent to which Mo scavenging occurs within the sediments as opposed to within the sulfidic water column, however, is still a matter of debate, as is the direct influence of organic matter (total organic carbon, TOC) supply to euxinic basins. In addition, the concentration of dissolved $\mathrm{Mo}$ in the bottom water may be a prominent factor for variable Mo concentrations in euxinic sediments (Algeo and Lyons, 2006).

Here we introduce molybdenum isotope compositions of surface sediments as a proxy for minimum water column sulfide concentrations based on results from the modern Black Sea and present an application of this approach to euxinic basins of the Baltic Sea.

\section{SAMPLES AND METHODS}

This study discusses results obtained from surface sediments in the Black Sea taken with multicoring devices in 2001 and 2007 during R/V METEOR cruises M51/4 and M72/5 (Fig. 1). Station 6 samples were obtained in 1997 during a cruise with R/V Petr Kottsov and results were taken from Nägler et al. (2005). Additional samples from the Baltic Sea (Gotland and Landsort Deep), were collected during the first scientific MS MERIAN cruise. All Mo isotopic compositions and concentrations 


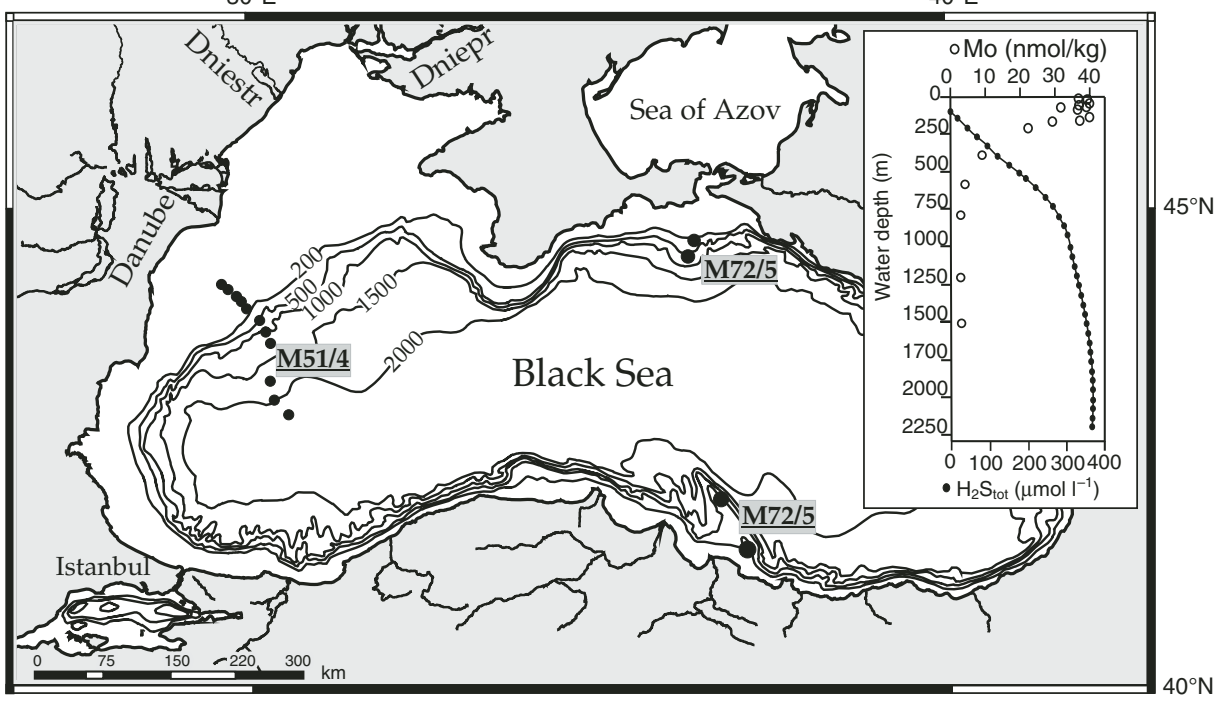

Figure 1. Map of Black Sea region showing sample locations (black dots). Inset shows Mo concentrations (open circles; Colodner et al. 1995) and dissolved sulfide concentration in the water column (black circles; after Neretin et al., 2001).

were measured by multicollector-inductively coupled plasma-mass spectrometry (MC-ICPMS) ( $\mathrm{Nu}$ instruments). The $\delta^{98 / 95} \mathrm{Mo}$ values are given as per mil deviations from an in-house standard solution (Siebert et al., 2001). The external reproducibility is better than $\pm 0.1 \%$ o ( 2 standard deviations). A detailed description of the analytical techniques was given in Siebert et al. (2001). Dissolved sulfide concentrations were measured spectrophotometrically (Cline, 1969). Bulk aluminum and manganese contents were measured after microwave or complete multiacid digestion using Varian or Thermo Electron ICP-optical emission spectrometry (OES) systems. TOC was calculated as the difference between total carbon and total inorganic carbon contents, measured using a CE elemental analyzer and a C-S Multi EA 2000 (Analytik Jena), respectively.

\section{RESULTS AND DISCUSSION}

All Mo data are presented in GSA Data Repository Table DR $1^{1}$ and in Figure 2. The sediment samples in this study represent a deep transect from the shelf break at $\sim 80 \mathrm{~m}$ water depth to the deep basin at $2100 \mathrm{~m}$ water depth. The surface sediments represent the first $0-1 \mathrm{~cm}$ below surface, while some deep-sea samples reach a few centimeters below surface

${ }^{1}$ GSA Data Repository item 2008201, Table DR 1 (elemental and isotope data), Figure DR1 (comparison of $\mathrm{H}_{2} \mathrm{~S}$ water column profile and bottom water $\mathrm{H}_{2} \mathrm{~S}$ at various sites from cruises M51/4 and M72/5), and Figure DR2 (plotted Mo isotopic composition against the Mo concentration), is available online at www.geosociety.org/pubs/ft2008.htm, or on request from editing@geosociety.org or Documents Secretary, GSA, P.O. Box 9140, Boulder, CO 80301, USA.
(Table DR1). The main observation is the difference between Mo data of shallower sediments (83 m to $396 \mathrm{~m}$ water depth), deposited under oxic to anoxic to slightly euxinic conditions and deeper, strongly euxinic sediments. This change in the Mo isotopic ratios is also reflected in the Mo concentrations. Results for the different regions of the Black Sea are consistent (Table DR1), and therefore all Mo data are discussed together. The deep euxinic sediments $>410 \mathrm{~m}$ water depth have a heavy Mo isotopic composition (2\%o-2.4\%o, $1.6 \%$ o at $400 \mathrm{~m}$ ) close to the modern seawater signal. Mo concentrations are highest at $\sim 400-500 \mathrm{~m}$, but decrease at greater depth, most probably due to concurrent water column depletion. Mo concentrations and isotopic compositions are thus not directly correlated (Fig. DR2; see
Figure 2. Left graph shows Mo concentrations in sediments along a deep transect. In middle graph, black circles are $\delta^{98 / 95} \mathrm{Mo}$ isotopic composition of recent $(0-10 \mathrm{~cm}$ below surface) sediments correlated with bottom water sulfide concentrations (right graph; diamonds based on Neretin et al. [2001], recalculated as $\mathrm{H}_{2} \mathrm{~S}_{\mathrm{aq}}$ following Almgren et al. [1976]). The two black and white dots are influenced by a detrital component (Table DR1; see footnote 1 ). footnote 1). In contrast, the shallower samples $(<272 \mathrm{~m}$ water depths) are significantly lighter in their isotopic composition, with $\delta^{98 / 95} \mathrm{Mo}$ values from $-0.6 \%$ o to $+0.9 \%$ and much lower concentrations. All data were corrected for detrital contribution, assuming detritus to have $[\mathrm{Al}]=8 \%$ (upper crust; Taylor and McLennan, 1995), $[\mathrm{Mo}]=1 \mathrm{ppm}$, and $\delta^{98 / 95} \mathrm{Mo}=0.3 \%$ o. The detrital contributions are very low for all samples (3\% of total Mo; Table DR1), except for one sample at $91 \mathrm{~m}$ water depth with $5 \%$ and two below the chemocline (Fig. 2; black and white dots) that are influenced by relatively high detrital contributions of $11 \%$ and $36 \%$. While the latter are still dominated by authigenic Mo, the uncertainties involved in the detritus correction are significant.

Several authors have shown field evidence for Mo isotope fractionation processes in reducing sedimentary environments (McManus et al., 2002; Nägler et al., 2005; Poulson et al., 2006; Siebert et al., 2006). Furthermore, theoretical calculations by Tossell (2005) showed that significant equilibrium Mo isotope fractionation is expected between different aqueous species, in particular between dissolved molybdate and thiomolybdates. As a consequence, the reflected seawater Mo isotopic compositions in the strong euxinic sediments (below $400 \mathrm{~m}$ ) is interpreted to reflect complete Mo scavenging from the water column and deposition in the surface sediments. Under these conditions, any process-related fractionation would be erased because of complete Mo removal in an effectively closed system, and the isotopic composition of the source is recorded. The lighter Mo isotopic compositions found in the shallower sediments, on the other hand, reflect incomplete removal of Mo from the water column, accompanied by bulk Mo isotope fractionation yielding enrichment of the lighter isotopes in this particulate fraction.
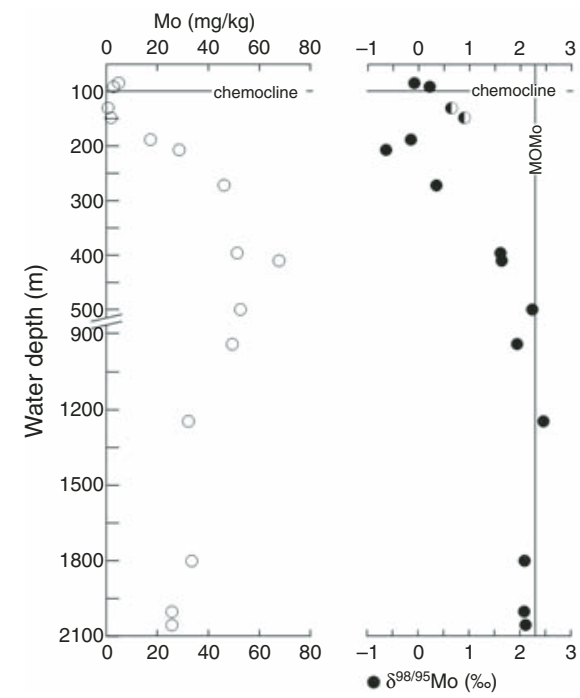

$\diamond \log \mathrm{H}_{2} \mathrm{~S}_{\mathrm{aq}}\left(\mu \mathrm{mol} \mathrm{I} \mathrm{I}^{-1}\right)$

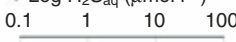

$\diamond$ $\diamond$ $\diamond$ $\diamond$ $\diamond$

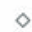

$\diamond$ 
An important question focuses now on the parameters controlling Mo scavenging in the Black Sea water column. Nägler et al. (2005) first presented Mo isotope evidence from a Black Sea sediment core recovered from 396 m water depth, containing sediments deposited under limnic (oxic) and marine (oxic and anoxic) conditions. Nägler et al. (2005) observed that Mo isotope fractionation is still preserved in the youngest samples (Unit I, Mo isotope values lighter than seawater at water depth of $396 \mathrm{~m}$ and euxinic conditions), in contrast to results reported by Arnold et al. (2004) from Black Sea sediments taken at a water depth exceeding $2000 \mathrm{~m}$. Nägler et al. (2005) put forward the hypothesis that Mo removal from the water column, and thus observable Mo isotope fractionation, depends on the aqueous $\mathrm{H}_{2} \mathrm{~S}\left(\mathrm{H}_{2} \mathrm{~S}_{\mathrm{aq}}\right)$ concentration. As a result, even under euxinic conditions an overall Mo isotope fractionation can occur if the sulfidity is low. Wille et al. (2008) successfully used this assumption of a light Mo isotopic sink under weak euxinic conditions to model an observed transient Mo isotopic signal across the Precambrian-Cambrian boundary. Erickson and Helz (2000) defined the action point of switch (APS), where water column $\mathrm{H}_{2} \mathrm{~S}_{\mathrm{aq}}$ concentrations must exceed $11 \mu \mathrm{mol}$ $\mathrm{L}^{-1}$ for thiomolybdate to dominate over molybdate $\left(\mathrm{MoS}_{4}^{2-}>>\mathrm{MoO}_{4}^{2-}\right)$. Note that at $\mathrm{pH}$ values of $\sim 8$, the $\mathrm{H}_{2} \mathrm{~S}_{\mathrm{aq}}$ content of $11 \mu \mathrm{mol} \mathrm{L} \mathrm{L}^{-1}$ is $\sim 100 \mu \mathrm{mol} \mathrm{L}^{-1} \mathrm{H}_{2} \mathrm{~S}_{\text {tot }}$. In the water column of the Black Sea the concentration of sulfide increases with water depth and reaches the APS at $\sim 400 \mathrm{~m}$ depth (Fry et al., 1991; Neretin et al., 2001) (Fig. 3A). The same $\mathrm{H}_{2} \mathrm{~S}$ profile is reflected in the bottom-water samples taken during cruises M51/4 and M72/5 at various depth (Fig. DR1).

Thus, at shallower depths molybdate coexists with thiomolybdate. This causes Mo isotope fractionation between the water column and a particulate reservoir, even if conditions are euxinic. In agreement with this model, the sediments deposited in $<400 \mathrm{~m}$ of water show Mo isotope fractionation and are depleted in the heavier Mo isotopes. Furthermore, the observed ratios can be reconciled with the theoretical calculations of Tossell (2005) for equilibrium fractionation between molybdate and thiomolybdate. At water depths $<200 \mathrm{~m}$ the most abundant species are $\mathrm{MoO}_{3} \mathrm{~S}^{2-}$ and $\mathrm{MoO}_{2} \mathrm{~S}_{2}^{2-}$, and at depths $>400 \mathrm{~m} \mathrm{MoOS}_{3}^{2-}$ and $\mathrm{MoS}_{4}^{2-}$ dominate (Fig. 3). The increasing Mo isotopic composition of $\mathrm{MoO}_{4}^{2-}$ through depth (Fig. 3B) reflects the preferential incorporation of lighter Mo isotopes in the thiomolybdate species that are surface reactive and leads to the removal of the lighter isotope into the solid phase. Thus the data set presented here clearly supports the hypothesis of water column $\mathrm{H}_{2} \mathrm{~S}_{\mathrm{aq}}$ control of the Mo isotopic composition recorded in euxinic organic-rich sediments. In particular, a minimum $\mathrm{H}_{2} \mathrm{~S}_{\text {aq }}$ concentration above the APS of $11 \mu \mathrm{mol} \mathrm{L}{ }^{-1}$ is required for a complete fixation of water column molybdate in the sediments. Note that suboxic continental shelf sediments generally have $\delta^{98 / 95} \mathrm{Mo}$ isotopic compositions between the minimum and maximum values of the Black Sea euxinic sediments (Siebert et al., 2006, Poulson et al., 2006). The conclusion is that the seawater Mo isotopic composition does not just reflect the balance between oxic and
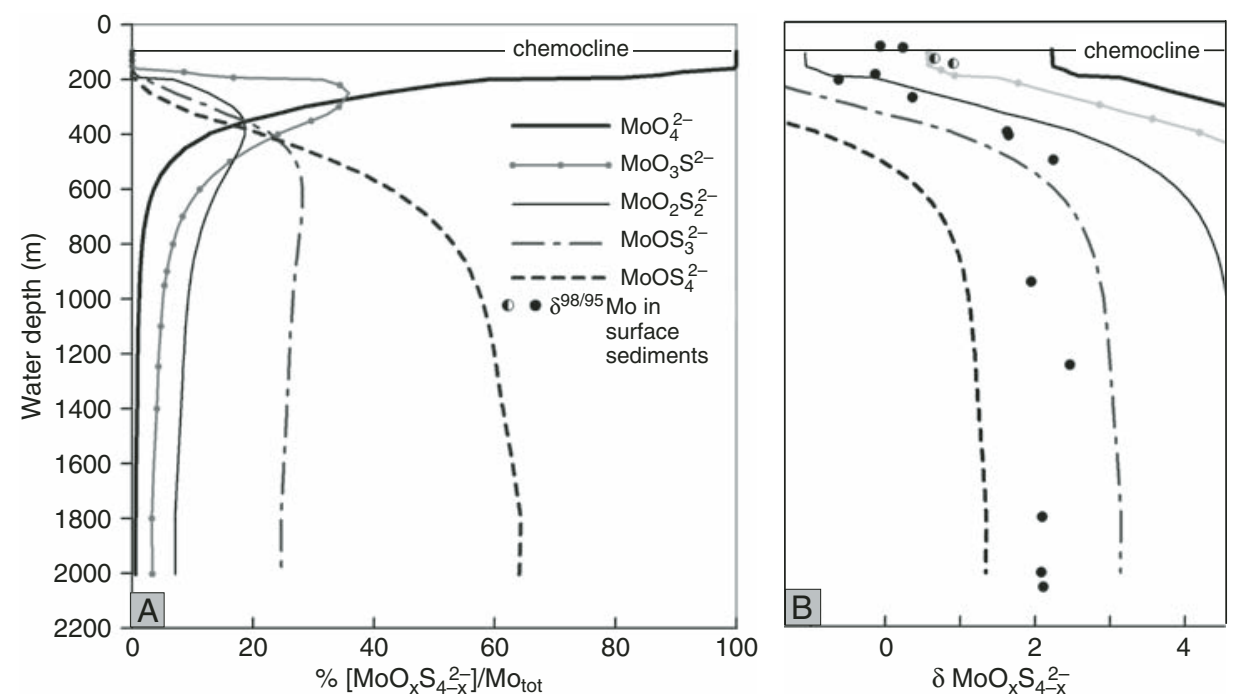

Figure 3. A: Graph shows depth profile of theoretical $\mathrm{H}_{2} \mathrm{~S}_{\mathrm{aq}}$-dependent Mo speciation below the chemocline. Calculations are based on the model of Erickson and Helz (2000), and sulfide concentrations taken from Neretin et al. (2001). B: Graph shows related Mo isotopic compositions of the respective species pools. Latter are based on the theoretical calculations of Tossell (2005) for Mo isotope fractionation between $\mathrm{MoO}_{4}^{2-}, \mathrm{MoO}_{2} \mathrm{~S}_{2}^{2-}$, and $\mathrm{MoS}_{4}^{2-}$. Isotope fractionation values of the remaining two thiomolybdate species are interpolated. $\delta^{98 / 95}$ Mo isotopes in recent Black Sea sediments clarify connection of the respective species.

anoxic sedimentation. Rather, the Mo isotopic composition acts as a proxy for more stringent conditions, namely the balance between strongly euxinic sedimentation with sulfidity above the APS, and all other environments having lower sulfidity, from weakly euxinic to anoxic to oxic. This must be considered in models of past ocean anoxia reconstruction.

In addition to the dependence of Mo removal from $\mathrm{H}_{2} \mathrm{~S}_{\mathrm{aq}}$, we have to consider the possible influence of organic matter accumulation on total Mo accumulation (Algeo and Lyons, 2006). A broad positive correlation between Mo isotope values and TOC in the sediments as well as $\mathrm{H}_{2} \mathrm{~S}_{\mathrm{aq}}$ in the water column (Figs. 4A and 4B) is seen above the APS (188-410 m). It is likely to be a secondary consequence of bottom water $\mathrm{H}_{2} \mathrm{~S}_{\text {aq }}$ broadly correlating with TOC in euxinic surface sediments. We argue, in line with the work of Erickson and Helz (2000) and Tossell (2005), that the closer correlation of Mo with $\mathrm{H}_{2} \mathrm{~S}_{\mathrm{aq}}$ rather than TOC argues for a
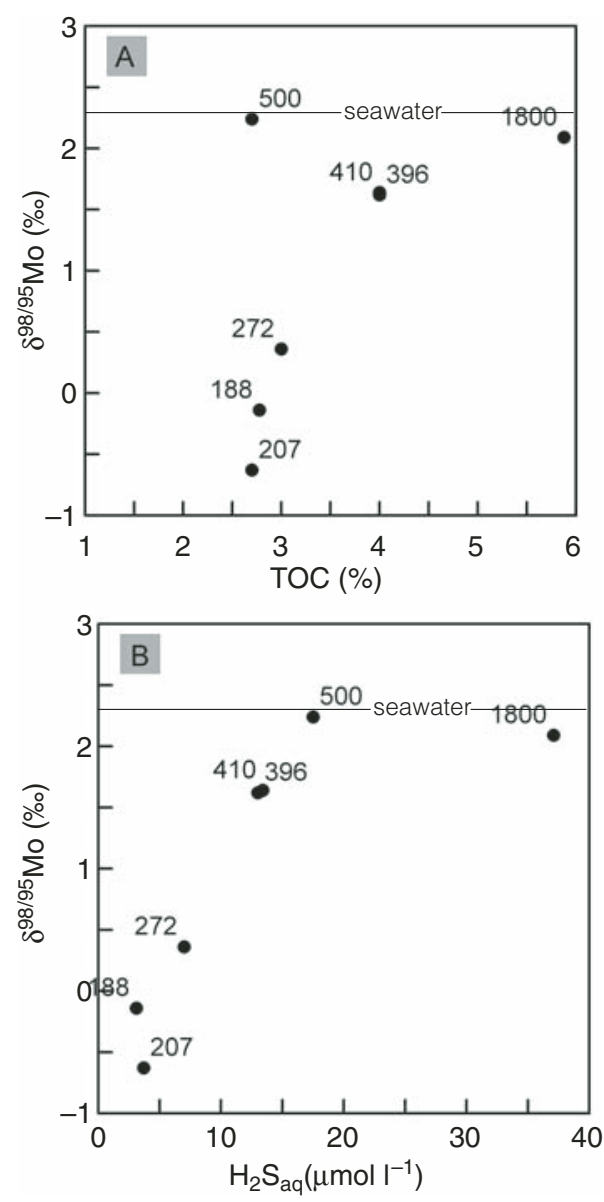

Figure 4. A: Mo isotopic composition plotted against total organic carbon (TOC). B: Mo isotopic composition plotted against aquatic sulfide content in the water column. All samples are below $188 \mathrm{~m}$ water depth (distinctly below chemocline). Numbers are water depths in meters. 
primary control by the minimum sulfide concentration in the water column (Fig. 4).

As additional modern examples, the results from surface sediments deposited in two euxinic basins of the Baltic Sea are presented in Table DR1. The critical APS is not reached in the water columns of these basins $(<3.1 \mu \mathrm{mol}$ $\mathrm{L}^{-1} \mathrm{H}_{2} \mathrm{~S}_{\mathrm{aq}}$ ). As a result, Mo is not completely removed from the water column, and the Mo isotopic ratio in the sediments is low relative to the seawater ratio. The overall fractionation, however, is smaller than in oxic Black Sea settings, as expected from the trends in Figure 2 and the low sulfide concentrations in the Baltic water columns.

\section{CONCLUSION}

The complete Mo geochemical and isotopic shelf-deep-sea profile of Black Sea surface sediments mirrors complete fixation of Mo below a water depth of $\sim 400 \mathrm{~m}$ and leads to a proxy transfer function, where complete Mo fixation can only occur at water column aquatic sulfide concentrations above the APS of $11 \mu \mathrm{mol} \mathrm{L}-1$ $\mathrm{H}_{2} \mathrm{~S}_{\mathrm{aq}}$. Below the APS, low sulfide concentrations in the water column cause fractionation in surface sediments. Consequently, reconstructions of past ocean anoxia should account for the balance between strong euxinic Mo sedimentation (i.e., with sulfidity above the APS) relative to all other environments, from oxic to anoxic to weakly euxinic, not just by the balance between oxic and anoxic sedimentation.

\section{ACKNOWLEDGMENTS}

We thank the captains and crews from cruise Meteor 51/4, 72/5, MSM Merian 01/1, and R/V Petr Kottsov for their invaluable support and excellent working atmosphere. We wish to thank Bo Jorgensen and Christian Borowski for leading the M51/4 and M72/5 cruises, respectively. We also thank Olaf Dellwig for sediment sampling onboard M72/5, and Andrea Schipper, Dagmar Benesch, Swantje Lilienthal, Reinhild Rosenberg, and Sylvia Klein for lab assistance at the Max Planck Institute for Marine Microbiology (MPI-MM), Bremen, and the Leibniz Institute for Baltic Sea Research, Warnemünde. The manuscript also benefited from helpful reviews of Anthony Cohen and two anonymous reviewers. The work is supported by the Swiss Science Foundation (200020-113658), the Leibniz Institute for Baltic Sea Research (IOW), and the Max Planck Society. Sampling by Böttcher in the northwestern Black Sea was supported by the Deutsche Forschungsgemeinschaft (JO 307/6-1).

\section{REFERENCES CITED}

Algeo, T.J., and Lyons, T.W., 2006, Mo-total organic carbon covariation in modern anoxic marine environments: Implications for analysis of paleoredox and paleohydrographic conditions: Paleoceanography, v. 21, PA1016, doi: 10.1029/2004PA001112.

Almgren, T., Dyrssen, D., Elgquist, G., and Johannson, O., 1976, Dissociation of hydrogen sulphide in seawater and comparison of $\mathrm{pH}$ scales: Marine Chemistry, v. 4, p. 289-297, doi: 10.1016/0304-4203(76)90014-1.

Arnold, G.L., Anbar, A.D., Barling, J., and Lyons, T.W., 2004, Molybdenum isotope evidence for widespread anoxia in mid-Proterozoic oceans: Science, v. 304, p. 87-90, doi: 10.1126/ science. 1091785

Barling, J., Arnold, G.L., and Anbar, A.D., 2001, Natural mass-dependent variations in the isotopic composition of molybdenum: Earth and Planetary Science Letters, v. 193, p. 447-457, doi: 10.1016/S0012-821X(01)00514-3.

Cline, J.D., 1969, Spectrophotometric determination of hydrogen sulfide in natural waters: Limnology and Oceanography, v. 14, p. 454-458.

Colodner, D., Edmond, J., and Boyle, E., 1995, Rhenium in the Black Sea-Comparison with molybdenum and uranium: Earth and Planetary Science Letters, v. 131, p. 1-15, doi: 10.1016/0012-821X(95)00010-A.

Crusius, J., Calvert, S., Pedersen, T., and Sage, D., 1996, Rhenium and molybdenum enrichments in sediments as indicators of oxic, suboxic and sulfidic conditions of deposition: Earth and Planetary Science Letters, v. 145, p. 65-78, doi: 10.1016/S0012-821X(96)00204-X.

Emerson, S.R., and Huested, S.S., 1991, Ocean anoxia and the concentrations of molybdenum and vanadium in seawater: Marine Chemistry, v. 34 , p. 177-196, doi: 10.1016/0304-4203 (91)90002-e.

Erickson, B.E., and Helz, G.R., 2000, Molybdenum (VI) speciation in sulfidic waters: Stability and lability of thiomolybdates: Geochimica et Cosmochimica Acta, v. 64, p. 1149-1158, doi: 10.1016/S0016-7037(99)00423-8

Fry, B., Jannasch, H.W., Molyneaux, S.J., Wirsen, C.O., Muramoto, J.A., and King, S., 1991, Stable isotope studies of the carbon, nitrogen and sulfur cycles in the Black Sea and the Cariaco Trench: Deep-Sea Research, v. 38, p. 1003-1019.

Helz, G.R., Miller, C.V., Charnock, J.M., Mosselmans, J.F.W., Pattrick, R.A.D., Garner, C.D., and Vaughan, D.J., 1996, Mechanism of molybdenum removal from the sea and its concentration in black shales: EXAFS evidence: Geochimica et Cosmochimica Acta, v. 60 , p. 3631-3642, doi: 10.1016/0016-7037 (96)00195-0

Konovalov, S.K., Eremeev, V.N., Suvorov, A.M., Khaliulin, A.K., and Godin, E.A., 1999, Climatic and anthropogenic variations in the sulfide distribution in the Black Sea: Aquatic Geochemistry, v. 5, p. 13-27, doi: 10.1023/A:1009655502787.

Lehmann, B., Nägler, T.F., Holland, H.D., Wille, M., Mao, J., Pan, J., Ma, D., and Dulski, P., 2007, Highly metalliferous carbonaceous shale and of Early Cambrian seawater: Geology, v. 35, p. 403-406, doi: 10.1130/G23543A.1.

McManus, J., Nägler, T.F., Siebert, C., Wheat, C.G., and Hammond, D.E., 2002, Oceanic molybdenum isotope fractionation: Diagenesis and hydrothermal ridge-flank alteration: Geochemistry, Geophysics, Geosystems, v. 3, p. 1078, doi: 10.1029/2002GC000356.

Murray, R.W., Top, Z., and Ozsoy, E., 1991, Hydrographic properties and ventilation of the Black Sea: Deep-Sea Research, v. 38, p. 663-689, doi: 10.1016/0198-0149(91)90005-Z.
Nägler, T.F., Siebert, C., Lüschen, H., and Böttcher, M.E., 2005, Sedimentary Mo isotope record across the Holocene fresh-brackish water transition of the Black Sea: Chemical Geology, v. 219, p. 283-295, doi: 10.1016/ j.chemgeo.2005.03.006.

Neretin, L.N., Volkov, I.I., Böttcher, M.E., and Grinenko, V.A., 2001, A sulfur budget for the Black Sea anoxic zone: Deep-Sea Research. Part I, Oceanographic Research Papers, v. 48, p. 2569-2593, doi: 10.1016/S09670637(01)00030-9.

Poulson, R.L., Siebert, C., McManus, J., and Berelson, W.M., 2006, Authigenic molybdenum isotope signatures in marine sediments: Geology, v. 34, p. 617-620, doi: 10.1130/G22485.1.

Ross, D.A., and Degens, E.T., eds., 1974, The Black Sea-Geology, chemistry and biology: American Association of Petroleum Geologists Memoir 20, p. 183-199.

Siebert, C., Nägler, T.F., and Kramers, J.D., 2001, Determination of molybdenum isotope fractionation by double-spike multicollector inductively coupled plasma mass spectrometry: Geochemistry, Geophysics, Geosystems, v. 2, doi: 10.1029/2000GC000124.

Siebert, C., Nägler, T.F., von Blanckenburg, F., and Kramers, J.D., 2003, Molybdenum isotope records as a potential new proxy for paleoceanography: Earth and Planetary Science Letters, v. 211, p. 159-171, doi: 10.1016/ S0012-821X(03)00189-4.

Siebert, C., Kramers, J.D., Meisel, T., Morel, P., and Nägler, T., 2005, PGE, Re-Os, and Mo isotope systematics in Archean and early Proterozoic sedimentary systems as proxies for redox conditions of the early Earth: Geochimica et Cosmochimica Acta, v. 69, p. 1787-1801, doi: 10.1016/j.gca.2004.10.006.

Siebert, C., McManus, J., Bice, A., Poulson, R., and Berelson, W.M., 2006, Molybdenum isotope signatures in continental margin marine sediments: Earth and Planetary Science Letters, v. 241, p. 723-733, doi: 10.1016/j.eps1.2005. 11.010 .

Taylor, S.R., and McLennan, S.M., 1995, The geochemical evolution of the continental crust: Reviews of Geophysics, v. 33, p. 241-265, doi: 10.1029/95RG00262.

Tossell, J.A., 2005, Calculating the partitioning of the isotopes of Mo between oxidic and sulfidic species in aqueous solution: Geochimica et Cosmochimica Acta, v. 69, p. 2981-2993, doi: 10.1016/j.gca.2005.01.016.

Wille, M., Kramers, J.D., Nägler, T.F., Beukes, N.J., Schröder, S., Meisel, T., Lacassie, J.P., and Voegelin, A.R., 2007, Evidence for a gradual rise of oxygen between 2.6 and $2.5 \mathrm{Ga}$ from Mo isotopes and Re-PGE signatures in shales: Geochimica et Cosmochimica Acta, v. 71, p. 2417, doi: 10.1016/j.gca.2007.02.019.

Wille, M., Nägler, T.F., Lehmann, B., Schröder, S. and Kramers, J.D., 2008, Hydrogen sulphide release to surface waters at the Precambrian/ Cambrian boundary: Nature, v. 453, p. 767769, doi: 10.1038/nature07072.

Manuscript received 17 March 2008

Revised manuscript received 8 June 2008

Manuscript accepted 16 June 2008

Printed in USA 